[Regular Paper]

\title{
Deformation Properties of Asphalt Mixture on Various Loading Conditions for Wheel Tracking Test
}

\author{
Takashi Kondo $^{\dagger 1) *}$, Akihiro MoriYoshi ${ }^{\dagger 2)}$, Takaki YoshIDA ${ }^{\dagger 1)}$, Shouichi TAKAHASHI ${ }^{\dagger 1)}$, and Takeshi IMAI ${ }^{\dagger 3)}$ \\ $\dagger^{1)}$ Dept. of Civil Engineering, Tomakomai National College of Technology, Nishikioka 443, Tomakomai, Hokkaido 059-1275, JAPAN \\ ${ }^{\dagger 2}$ Graduate School of Engineering, Hokkaido University, Nishi 8, Kita 13, Kita-ku, Sapporo 060-8628, JAPAN \\ ${ }_{\dagger 3}$ Toa Doro Kogyo Co., Ltd., Higashikariki 5-jo 1-1-18, Higashi-ku, Sapporo 007-0825, JAPAN
}

(Received May 6, 2004)

\begin{abstract}
The movement characteristics of aggregates in asphalt mixtures were investigated with wheel tracking tests under the following loading conditions: reciprocating motion, one-way motion, and one-way motion with braking. The outside wheel tracking tests used fine and gap graded (13F) asphalt mixtures.

The tests showed that the amount of rutting in one-way motion was larger than that in reciprocating motion. In the case of reciprocating motion, the surface heaved up at the right load end. In the case of one-way motion, the surface heaved up at the point $50 \mathrm{~mm}$ from both contact ends of the tire. Consolidation caused the rutting phenomenon during reciprocating motion, and flow caused the rutting phenomenon during one-way motion, based on the movement of aggregates as viewed from the right-angle direction to the loading. Therefore, the rutting phenomenon including the deformation in the transverse direction can be analyzed by wheel tracking tests based on one-way motion, or reciprocating motion, using the conventional wheel tracking test.

However, in the case of rutting during one-way motion with braking, the movement of aggregates in the wheel direction caused by tire friction was larger than movement in the depth direction. The inside of the asphalt mixture was dragged by tire friction in the wheel direction. Therefore, at locations where brake operation is frequently needed, the rutting phenomenon caused by flow and abrasion will be greater.
\end{abstract}

\section{Keywords}

Asphalt mixture, Wheel tracking test, Loading condition, Reciprocating motion, One-way motion,

Brake motion

\section{1. 緒言}

アスファルト舗装は，高温時に車両走行部でわだち掘れが生 じ，また車両のブレーキ操作が頻繁に必要となる場所では摩耗 による損傷が生じる。そのため, アスファルト混合物の耐流動 特性の評価はホイールトラッキング試験（以下, WT試験), 耐摩耗特性の評価はラベリング試験により行われている。

一方，国土交通省は平成 13 年 7 月 1 日に施行された道路構造 令の改定に伴い, 道路舗装工事の発注方法を従来の仕様規定方 式から性能規定方式とした1)。これにより，受注者による新技 術の開発・普及の促進, 品質・性能の向上，工期の短縮などが 期待されることとなった。この性能規定には，完成時の耐塑性 変形, 透水性, 平たん性, 騒音值などが多く用いられている。 この性能規定の一つである耐塑性変形は, WT試験による動的 安定度（DS: Dynamic Stability）により表されることから，こ れまで以上にWT試験が重要視されることとなると考えられ る。

現在, 我が国のWT試験は, 日本道路協会の舗装試験法便覧

\footnotetext{
* To whom correspondence should be addressed.

* E-mail: kondo@civil.tomakomai-ct.ac.jp
}

別冊2)に示されているように，イギリスの交通研究所（TRL: Transportation Research Laboratory) で開発されたWT試験機と 同様の試験機を使用して行われている。

また，各国で行われているWT試験は，実験温度および走行 回数などの試験条件が多様であるが, わだち掘れの発生に大き な影響を与えると考えられるアスファルト混合物上を走行する 輪荷重のタイプも多様である。ここで, 輪荷重の種類を挙げる と以下のようになる3) 5)。

(1) ソリッドゴムタイヤによる走行（TRL, 日本で主に使用さ れている)

（2）ニューマティックタイヤによる走行（FRT: French Rutting Tester)

（3）鉄輪による走行 (HWTD: Hamburg Wheel Tracking Device) (4) アルミニウム輪による空気入りゴムホース上の走行 (APA: Asphalt Pavement Analyzer, GLWT: Georgia Loaded Wheel Tester)

などがあり，これらのWT試験はいずれも往復走行により行わ れている。また, 各走行輪によるWT試験結果から得られる変 形一時間曲線はいずれの結果においても同様の形状となる。し かし, 実際のアスファルト舗装での車両走行は一方向となるこ とが大部分であるためWT試験時の走行方向とは異なる。 
Table 1 Gradation of Mixture

\begin{tabular}{|c|c|c|c|c|c|c|c|c|}
\hline Sieve opening $[\mathrm{mm}]$ & 19.0 & 13.2 & 4.75 & 2.36 & 0.6 & 0.3 & 0.15 & 0.075 \\
\hline Passing weight [\%] & 100.0 & 99.7 & 70.0 & 55.0 & 48.1 & 28.6 & 13.8 & 10.3 \\
\hline
\end{tabular}

一方向走行によるアスファルト混合物のWT試験を行った研 究は少ないが，佐野はWT試験機を改良し一方向走行でWT試 験を行い, 往復走行と一方向走行では荷重載荷部の変形量およ び横断方向への隆起の発生箇所に違いが現れることを報告して いる ${ }^{6}$ 。このことは，車両走行時のアスファルト混合物の変形 性状に関して，非常に重要な知見であると考えられる。

アメリカの連邦道路局（FHWA: U.S. Department of Transportation's Federal Highway Administration) がネバダ州で行った WesTrackでのトラック走行による実物大実験7),8) は，WT試験 とは異なるが一方向走行によるわだち掘れに関する研究と位置 付けられると考えられ，舗装体としてのアスファルト混合物に 生じるわだち掘れに関する報告がされている。また， WesTrackでのわだち掘れ量と各種 WT試験によるわだち掘れ 量の間に相関性があることを明らかにしている3) が，内部や横 断方向への変形などの相関性は明らかにされていない。

よって，一方向走行によるWT試験やわだち掘れに関する実 験を行い，往復走行との相違を明らかにすることは，わだち掘 れ現象の解明に非常に重要であると考えられる。

そこで, 本研究では既存のWT試験機を改良して往復走行, 一方向走行でのWT試験を行い，アスファルト混合物内部の骨 材の動きから走行方法の違いによるアスファルト混合物の表面 および内部の変形特性の相違を明らかにすることを目的とし た。また，ブレーキ走行によるWT試験を行い，アスファルト 舗装において短時間で表面に損傷が現れることとなるタイヤの 摩擦により摩耗が生じるアスファルト混合物の内部の骨材の動 きも明らかにした。

\section{2. 実験および解析方法}

\section{1. 実験に使用したアスファルト混合物の選定}

WT試験に使用したアスファルト混合物は，細粒度ギャップ アスファルト混合物（13F） と同一の配合で，アスファルトバ インダーとして改質アスファルトII型を用いたアスファルト混 合物（以下，細粒 G13F55）とした。

ここで，細粒度ギャップアスファルト混合物（13F）は北海 道における表層舗装として広く使用されており，細粒G13F55 は北海道に扔ける表層用アスファルト混合物で, 耐流動性を要 する舗装部に使用されているアスファルト混合物である。

\section{2. 使用材料および供試体作製方法}

細粒 G13F55 に使用したアスファルトバインダーの性状は密 度 $1.025 \mathrm{~g} / \mathrm{cm}^{3}$, 針入度 59 , 軟化点 $60.0^{\circ} \mathrm{C}$ であり, アスファル 卜混合物はアスファルト量 $6.0 \%$, 目標空げき率 $3.7 \%$, 転圧温 度 $160^{\circ} \mathrm{C}$, 目標舗装厚さ $50 \mathrm{~mm}$ とした。使用骨材の粒度を Table 1に示す。

試験舖装場では施工前にタンデムローラーにより施工面を往 復し，平たん性抢よび地盤支持力が一様であることを確認した 後, 既存の表層（細粒度ギャップアスファルト混合物）の上か ら施工を行った。敷きならしおよび転圧は現場施工時と同様
Table 2 Specifications of Rollers

\begin{tabular}{lccc}
\hline Item & Wheel & Tandem roller & Tire roller \\
\hline Total weight $[\mathrm{t}]$ & - & 7.0 & 15.0 \\
Quality of wheel & - & steel & rubber \\
Number of wheels & front & 1 & 3 \\
& rear & 1 & 4 \\
Wheel load [kN] & front & 33.3 & 62.8 \\
& rear & 36.3 & 84.3 \\
Driving wheel & front & yes & none \\
& rear & yes & yes \\
\hline
\end{tabular}

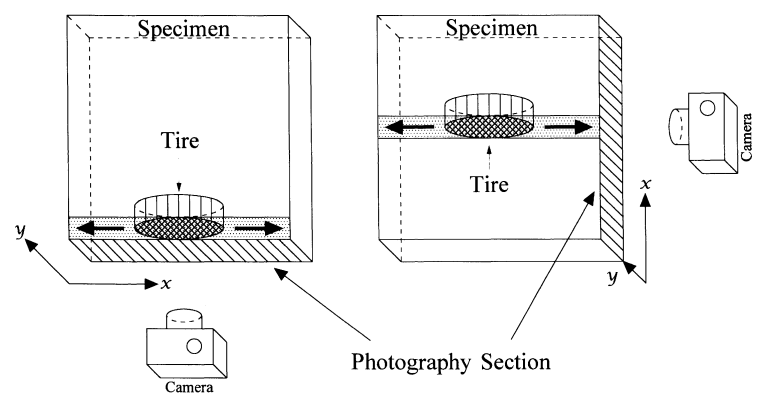

(a) Wheel Direction

(b) Vertical Direction

Fig. 1 Direction of Photography

に，アスファルトフィニッシャーで敷きならしを行った後，一 次転圧としてタンデムローラーを 3 回, 二次転圧としてタイヤ ローラーを 5 回走行させた。Table 2 に施工機械の特性を示す。 また，切り出し供試体の形状は幅 $280 \mathrm{~mm} \times$ 奥行き $280 \mathrm{~mm} \times$ 高 さ $50 \mathrm{~mm}$ とした。

\section{3. 実験および画像解析方法}

WT試験の温度条件は北海道での夏場の気温状態を考え, 試 験室内の温度を $45^{\circ} \mathrm{C}$ とし, 供試体底面の温度は供試体型枠底 面に水循環装置を取り付け $28^{\circ} \mathrm{C}$ とした。ここで, 底面の温度 条件は現場で測定された舗装表面の温度と内部温度のデー夕を 基に設定した。そして, WT試験機上に供試体を入れた型枠を 設置して, 約 24 時間の養生により供試体内の温度分布が定常 状態となった後に各種のWT試験を行った。

走行輪は，通常のWT試験と同様のソリッドゴムタイヤ車輪 (直径 $200 \mathrm{~mm}$, 幅 $50 \mathrm{~mm}$ ), 輪荷重は $540 \mathrm{~N}$ (接地圧 $0.54 \mathrm{MPa}$ ) である。

ここで, 往復走行では 42 pass/min で約 1 時間（2500 pass）走 行し，一方向走行およびブレーキ走行では走行輪が端部に達し た後上昇し, 始点に戻り再載荷されるため 21 pass/min で約 2 時 間（2500 pass）走行した。たたし, 走行輪の移動速度はいずれ の走行に扔いても同一である。また, 施工時の転圧方向とWT 試験時の走行方向を一致させた。

Fig. 1にWT試験時の写真撮影の方向を示す。Fig. 1(a) に示 


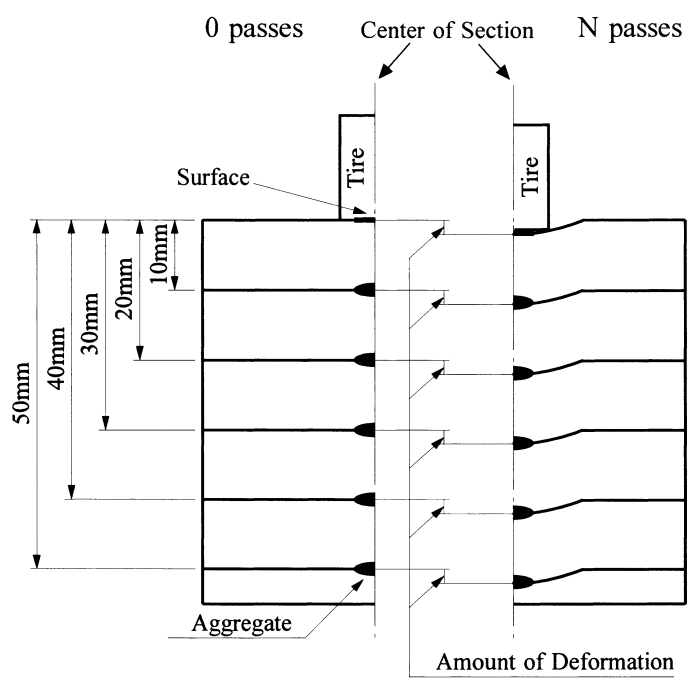

Fig. 2 Analysis Method for Movement of Aggregates

した方法により，荷重載荷位置を供試体手前として荷重載荷部 直下の側面の写真を撮影し, 往復走行, 一方向走行およびブ レーキ走行時における維断方向への骨材の動きの解析を行った （以下，Fig. 1(a) の載荷方法および写真撮影の方向を荷重側面 方向とする)。また，Fig. 1(b)に示した方法により，荷重載荷 位置を供試体型朹中央として荷重載荷部を中心とした荷重直角 方向の写真を撮影し，往復走行および一方向走行時における横 断方向への骨材の動きの解析を行った（以下，Fig. 1(b) の載 荷方法および写真撮影の方向を荷重直角方向とする)。

いずれの方法ともに，写真撮影面の供試体型枠をガラス板と して $35 \mathrm{~mm}$ カメラより 100 passごとに骨材の動きを撮影し た。

画像解析は実験時に撮影した $35 \mathrm{~mm}$ フィルムのネガをス キャナーで読みとり，PC上でスケールおよび角度などを一致 させた後に行った。また，本解析では撮影された供試体側面の 骨材で長径が約 $1 \mathrm{~mm}$ 以上の骨材を対象として, 撮影された断 面で観察される全ての骨材の動きおよび回転をxy方向（Fig. 1 参照）の2次元的な解析を行った。

\section{3. 結果および考察}

\section{1. 表面と深さごとの変形-時間曲線の関係}

\subsection{1. 解析方法}

解析は，往復走行および一方向走行ともにWT試験時に荷重 直角方向から撮影を行った画像を使用した。

表面の変形量と深さごとの変形量は，WT試験時の 100 pass ごとの画像から Fig. 2 のよう求めた。表面の変形量は荷重載 荷部中央の変形量とし, 深さ方向の変形量は表面から $10 \mathrm{~mm}$ ごとに求めた。変形量の計算は, 0 pass時を基準として表面か ら鉛直下方向へ $10 \mathrm{~mm}$ ごとに水平に線を描き，この線上にあ

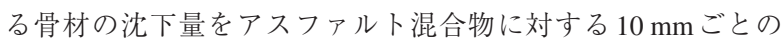
変形量と定義することとした。また，解析対象骨材として，荷 重載荷部の中央付近で観察される骨材を2 3 個選定した。

\subsection{2. 表面の変形に対する検討}

Fig. 3 に往復走行, Fig. 4 に一方向走行の解析結果より得ら

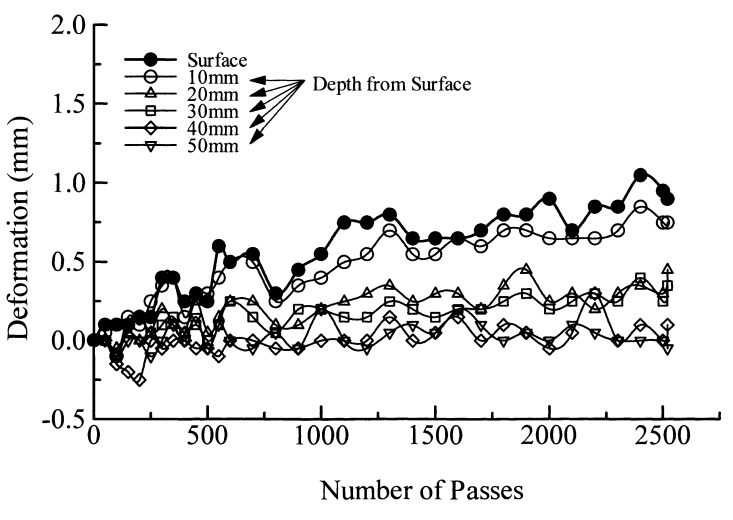

Fig. 3 Result of Wheel Tracking Test (reciprocating motion)

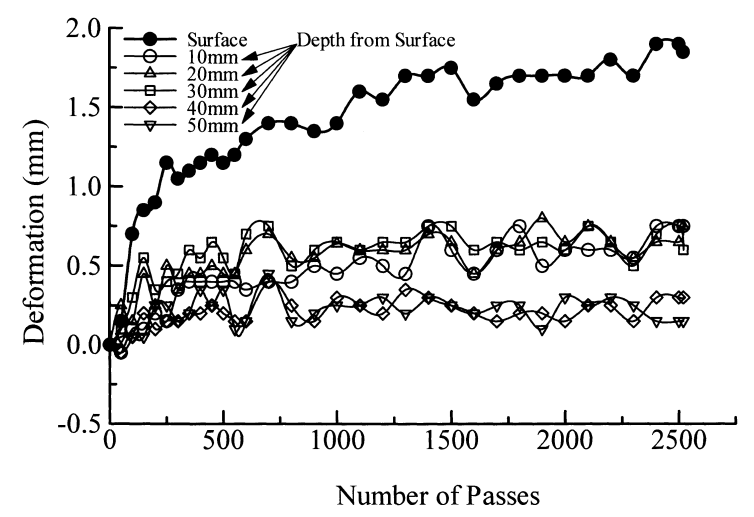

Fig. 4 Result of Wheel Tracking Test (one-way motion)

\section{れた表面と深さごとの変形-時間曲線を示す。}

Figs. 3，4より，WT試験（2500 pass）後の表面の変形量は 往復走行では $0.90 \mathrm{~mm}$, 一方向走行では $1.85 \mathrm{~mm}$ であり, 一方 向走行の変形量が大きな值となることは, 既往の研究結果 ${ }^{3)}$ と 同様の傾向を示している。

しかし, DS (WT試験開始後 45 分と 60 分の 15 分間に扔ける 単位変形量あたりの車両通過回数変形量, と定義されている) の計算を行うと両者ともに 3150 回 $/ \mathrm{mm}$ となり差が現れていな い。これは, Fig. 5 に一例として示したように, WT試験結果 から得られた 60 分後の表面の変形量に差が生じていても, 初 期の走行によりアスファルト混合物内部で空げきの減少や骨材 のかみ合わせに変化などが生じ，より安定した状態となった後 に変形-時間曲線の傾きが同一となった場合には, DS は同じ值 となるためである。このことは, DS という数值化されたデー 夕のみでは, 実際のアスファルト舗装に生じるわだち掘れ量の 推定を行うことは困難であることを示している。しかし, DS を圧密変形が終了した後に生じる長期的な流動特性を表す数值 としてとらえるのであれば，走行方法による影響は現れていな いことから, 往復走行によるWT試験結果から得られたDSに より長期的な流動特性の検討を行うことに問題はないと考えら れる。

また, 圧密変形量 $\left(d_{0}\right.$ : consolidated deformation, WT試験開 始後 45 分と 60 分の 15 分間の変形-時間曲線を延長して, 縦軸 との交点を表す変形量, として定義されている）の計算を行っ 


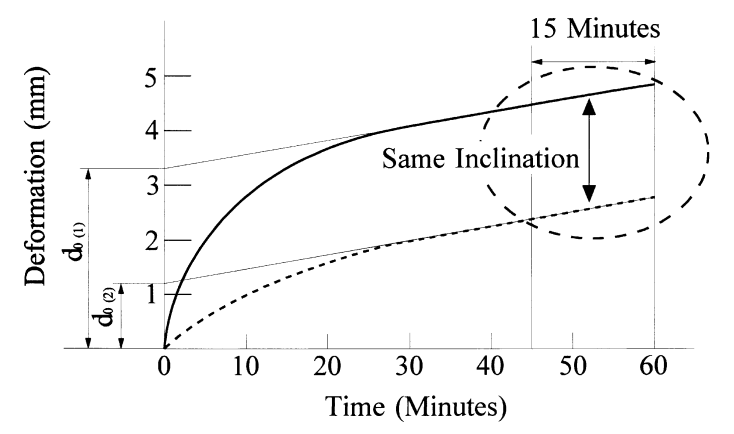

Fig. 5 Example of Relationship between Deformation and Time

た結果，往復走行では $d_{0}=0.28 \mathrm{~mm}$, 一方向走行では $d_{0}=1.04$ $\mathrm{mm}$ となった。これは, Fig. 5に一例として示したように, $D S$ が同じ值であっても $d_{0(1)}$ と $d_{0(2)}$ ではWT試験時における初期の 走行での圧密量が $d_{0(1)}$ の方が大きいため, 計算される $d_{0}$ もき くなるためである。このことから， $d_{0}$ はWT試験時における初 期の走行での圧密量に影響されることとなる。よって，本実験 の結果より，圧密変形量に違いが現れていることから，異なる 走行方法でWT試験を行った場合には，初期の走行におけるア スファルト混合物内部の動きが異なるものと考えられる。

\subsection{3. 表面と深さごとの変形}

Figs. 3，4より，アスファルト混合物内部の骨材の動きも表 面と同様に往復走行より一方向走行の方が大きい。また，Fig. 3 より往復走行時の表面と媣さごとの変形量は, 表面から 10 $\mathrm{mm}$ ごとにほぼ深さ方向の順番で減少している。しかし，Fig. 4より一方向走行時の表面と深さごとの変形量は, 表面から 10 $\mathrm{mm}$ ごとにほぼ深さ方向の順番で減少しているが, 表面と表面 から深さ $10 \mathrm{~mm}$ の変形量に大きな差が生じている。このこと から, 前項 (3.1.2.) での考察と合わせると, 一方向走行によ るWT試験における走行荷重直下のアスファルト混合物の圧密 変形は表面から深さ $10 \mathrm{~mm}$ 程度において大きく, 特に初期の 走行時に大きく影響を受けるものと考えられる。

\section{2. WT 試験時の体積変化}

\section{2. 1. 各期ごとの体積変化}

各期ごとの体積の計算は，WT試験時の 0，600，1900，2500 passの荷重直角方向の供試体断面の画像を使用した。ここで, 走行回数の選定は著者らがこれまでに行った研究 ${ }^{9}$ により, 初 期（First stage， 0 600 pass）で荷重載荷部の圧密変形が終了 し, 中期（Second stage， 600 1900 pass）で側方部への流動が 卓越し，後期（Final stage，1900～2500 pass）で骨材の動きは ほとんど生じなくなることを明らかにした。そこで，本研究に おいても同様の走行回数の画像を使用して解析を行うこととし た。また，部分的な体積変化の検討を行うために体積の計算は 荷重載荷部（3rd Part），荷重端部から $50 \mathrm{~mm}$ まで（左側: 2nd Part, 右側: 4th Part), 荷重端部から $50 \mathrm{~mm}$ 以上離れた部分（左

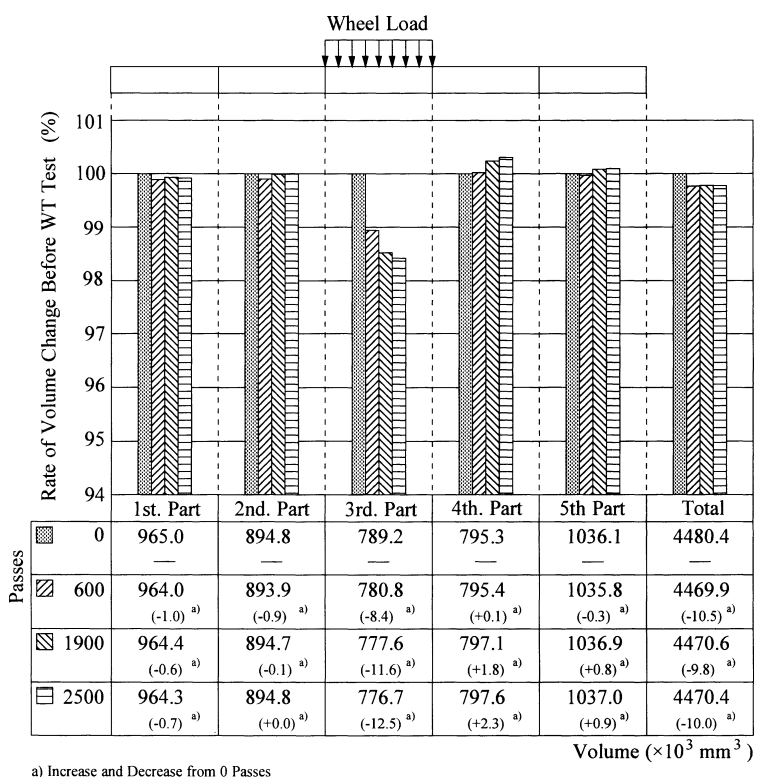

Fig. 6 Volume Change of Asphalt Mixture during the Wheel Tracking Test (reciprocating motion)

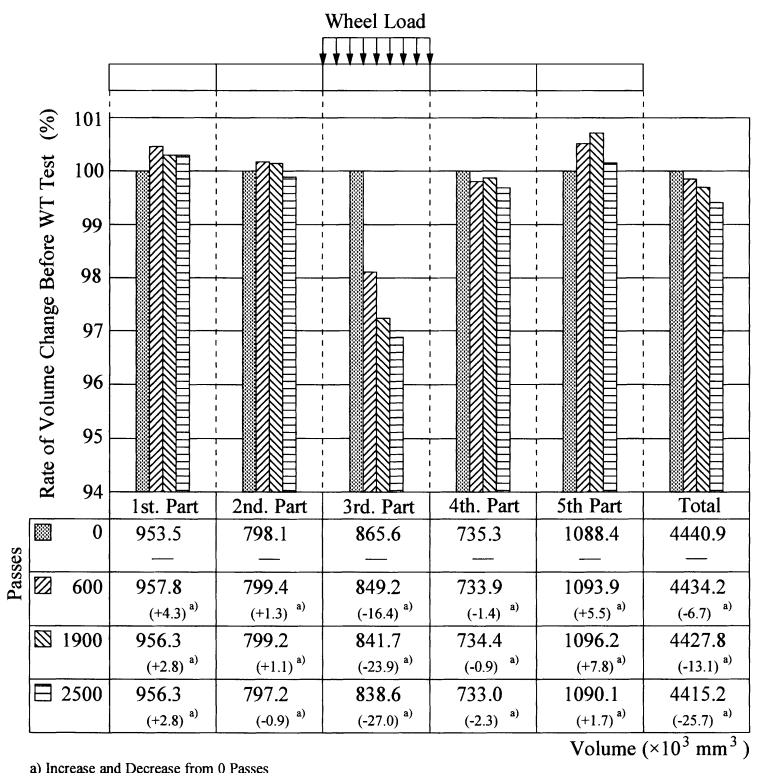

Fig. 7 Volume Change of Asphalt Mixture during the Wheel Tracking Test (one-way motion)

側: 1st Part, 右側: 5th Part）の5分割により行い, 全体の体積変 化はこれら5分割した体積の合計とした。

Fig. 6 に往復走行, Fig. 7 に一方向走行時の供試体の一定幅 断面より求めた体積の変化を示す。ここで, Figs. 6, 7 におけ る棒グラフは各P art および全体の 0 pass 時の体積を $100 \%$ とし たときの走行回数ごとの変化の割合を示し, 表中の数值は解析 により得られた走行回数ごとの体積を示す。また，括弧内には 各Part および全体の 0 pass 時の体積に対する走行回数ごとの体 積の増減を示した。

荷重載荷部の体積の減少は, 往復走行より一方向走行の方が 
大きい。これは，Figs. 3，4 に示した変形-時間曲線からも明 らかである。往復走行での体積の減少は初期に大きく, 中期で はほぼ終了している。また，一方向走行での体積の減少は初期 に大きく，後期ではやや小さくなるがWT試験全体を通して体 積が減少している。

往復走行では，4th Partで体積が増加しているが，その他の 部分の体積はほとんど変化していない。しかし，一方向走行で は2nd，4th Partでの体積はほとんど変化していないが，1st， 5th Partで体積が増加している。

全体の体積の変化より, 往復走行では初期に体積が減少し, 中期以降は変化していなが，一方向走行では各期ごとに体積が 減少している。

\section{2.2. 体積変化からの変形特性の推定}

Figs. 6，7 に示した体積変化において，荷重載荷部では走行 荷重が直接作用するため体積は減少しているが，1st，2nd，4th， 5th Part（以下，側方部と記す）の体積変化は走行方法によっ て異なっている。ここでは, 既報9) と同様に部分的な体積変化 により, 荷重載荷部の変形に対する圧密と流動の推定を行う。

また，著者らは既報9)において，WT試験後のアスファルト 混合物は部分的に密度の変化が生じており, 荷重載荷部では密 度が増加し, 荷重側方部では密度が減少し, 深さ方向の変化の 割合は上部から下部へと順に小さくなることを明らかにした。 よって, 本実験で使用したアスファルト混合物においても，推 定した荷重載荷部の圧密量および流動量は得られた数值より小 さくなると考えられる。

往復走行の 0 ～ 600 pass（初期）では，荷重載荷部および側 方部の体積ともに減少していることから, 荷重載荷部の変形は 圧密によるものであると考えられる。しかし，0１900 passで は荷重載荷部の体積の減少が $11.6 \times 10^{3} \mathrm{~mm}^{3}$ に対して, 側方部 の体積の増加の合計が $4.0 \times 10^{3} \mathrm{~mm}^{3} \quad(0 \sim 600$ pass（初期）では 流動が生じていないと考え 600 1900 pass（中期）での増加量 で検討を行う）であり, 荷重載荷部の変形の $34 \%(4.0 / 11.6=$ 0.34）が流動であると考えられる。同様に，0２500 passでは 荷重載荷部の体積の減少が $12.5 \times 10^{3} \mathrm{~mm}^{3}$ に対して, 側方部の 体積の増加の合計が $4.6 \times 10^{3} \mathrm{~mm}^{3} \quad(0 \sim 600$ pass（初期）では流 動が生じていないと考え600 2500 passでの増加量で検討を行 う）であり，荷重載荷部の変形の $37 \%(4.6 / 12.5=0.37 ）$ が流 動であると考えられる。

一方向走行の $0 \sim 600$ pass（初期）では荷重載荷部の体積の 減少は $16.4 \times 10^{3} \mathrm{~mm}^{3}$ に対して, 側方部の体積の増加が $9.7 \times$ $10^{3} \mathrm{~mm}^{3}$ であることから, 荷重載荷部の変形の 59\%（9.7/16.4= 0.59）が流動であると考えられる。同様に，0１900 passでは 荷重載荷部の体積の減少が $23.9 \times 10^{3} \mathrm{~mm}^{3}$ に対して, 側方部の 体積の増加が $10.8 \times 10^{3} \mathrm{~mm}^{3}$ であることから, 荷重載荷部の変 形の $45 \%(10.8 / 23.9=0.45), 0 \sim 2500$ pass では荷重載荷部の体 積の減少が $27.0 \times 10^{3} \mathrm{~mm}^{3}$ に対して, 側方部の体積の増加が $2.3 \times 10^{3} \mathrm{~mm}^{3}$ であることから, 荷重載荷部の変形の $9 \%$ $(2.3 / 27.0=0.09)$ が流動であると考えられる。

以上より, 往復走行での荷重載荷部の変形は初期で圧密によ り体積が減少し, その後側方部への流動により体積が減少して いくと考えられる。一方向走行での荷重載荷部の変形は, 1900 pass までの側方部への流動の割合が $45 \%$ 以上と非常に大きく,
圧密および流動が同時に生じ，体積が減少すると考えられる。 また, 1900 pass 以降は荷重載荷部の圧密による体積の減少の 割合が増加している。

よって, 走行方法が異なるとアスファルト混合物に生じる体 積変化掞よび変形の過程に違いが現れることが明らかとなっ た。

\section{3. 骨材の動きおよび回転}

\subsection{1. 解析方法および解析図の解説}

解析は, 3.2.1. と同様にWT試験による全走行回数を 3 段階 に分け，各期間の骨材の動きについて検討を行った。また，考 察対象部分を明確にするために, 解析結果には $10 \mathrm{~mm} \times 10 \mathrm{~mm}$ の格子を描いた。以下, 考察対象位置は供試体左側より深さ方 向は層, 横方向へは列と表記する。

解析結果を示したFigs. 8〜11，14中の矢印は線分が骨材の 移動量, 矢印が移動方向を表している。ただし, 本解析結果か ら得られた骨材の動きは非常に小さいため, 移動量を5倍にし て作図することとした。合わせて, 骨材の動きに応じて矢の大 きさを変化させた。骨材の動きに伴う回転を表すための記号 は, 四角 $(\square)$ は時計回り, 丸 $(\bigcirc)$ は反時計回りを表し, 大 きな回転が生じている骨材は記号を太線にして表した。ブレー キ走行では, 摩耗により供試体表面付近が削られるため, 走行 回数の増加によりなくなる骨材が生じる。この骨材は, 中空の 点で表すこととした。また, 荷重側面方向からの解析結果を示 したFig. 11 (一方向走行) およびFig. 14 (ブレーキ走行) に おいて, 走行輪の走行方向は供試体左側から右側である。

\subsection{2. 荷重直角方向の骨材の動きおよび回転}

Fig. 8 に往復走行, Fig. 9 に一方向走行時の荷重直角方向の 解析結果を示す。

\section{(1) 初期の動き}

両走行方法ともに骨材は, 荷重載荷部では鉛直下方向への動 きが大きく, 荷重側方部では左右の供試体型枠方向へと動いて いる。しかし, 荷重載荷部での骨材の動きは一方向走行の方が 大きく, 大きな回転を伴う骨材も多い。また, 荷重側方部の骨 材の供試体型枠方向への動きは, 往復走行では荷重載荷部より $50 \mathrm{~mm}$ 程度までの動きが大きく, それ以上離れた部分では動き が小さいのに対し, 一方向走行では両端まで動きが大きい。往 復走行では, 荷重載荷部の右側（19２1列）の上部で隆起す る方向へと骨材が動いているが, その他の部分では側方へ動い ており隆起する方向への動きは見られない。一方向走行では, 荷重載荷部から $50 \mathrm{~mm}$ 程度（7～11列， 17〜21列）の骨材は主 に側方㧍よび鉛直下方向へ動いている。しかし, 荷重載荷部か ら 60〜80 mm程度（5７列， 22〜24列）離れた部分の上部で は隆起する方向へ動いている骨材の見られる。

よって, 走行方法の違いにより, WT試験時のアスファルト 混合物の荷重直角方向では隆起する方向へ動く骨材の現れる箇 所が異なることが明らかとなった。

(2) 中期の動き

両走行方法ともに, 荷重載荷部では表面から深さ $30 \mathrm{~mm}$ 程 度までの骨材は鉛直下方向㧍よび側方へ動いている。また，一 方向走行の骨材の方が往復走行の骨材より鉛直下方向への動き が大きく, 大きな回転を示す骨材も多い。そして, 荷重載荷部 の表面から $30 \mathrm{~mm}$ 以下㧍よび荷重側方部の骨材は側方へと動 

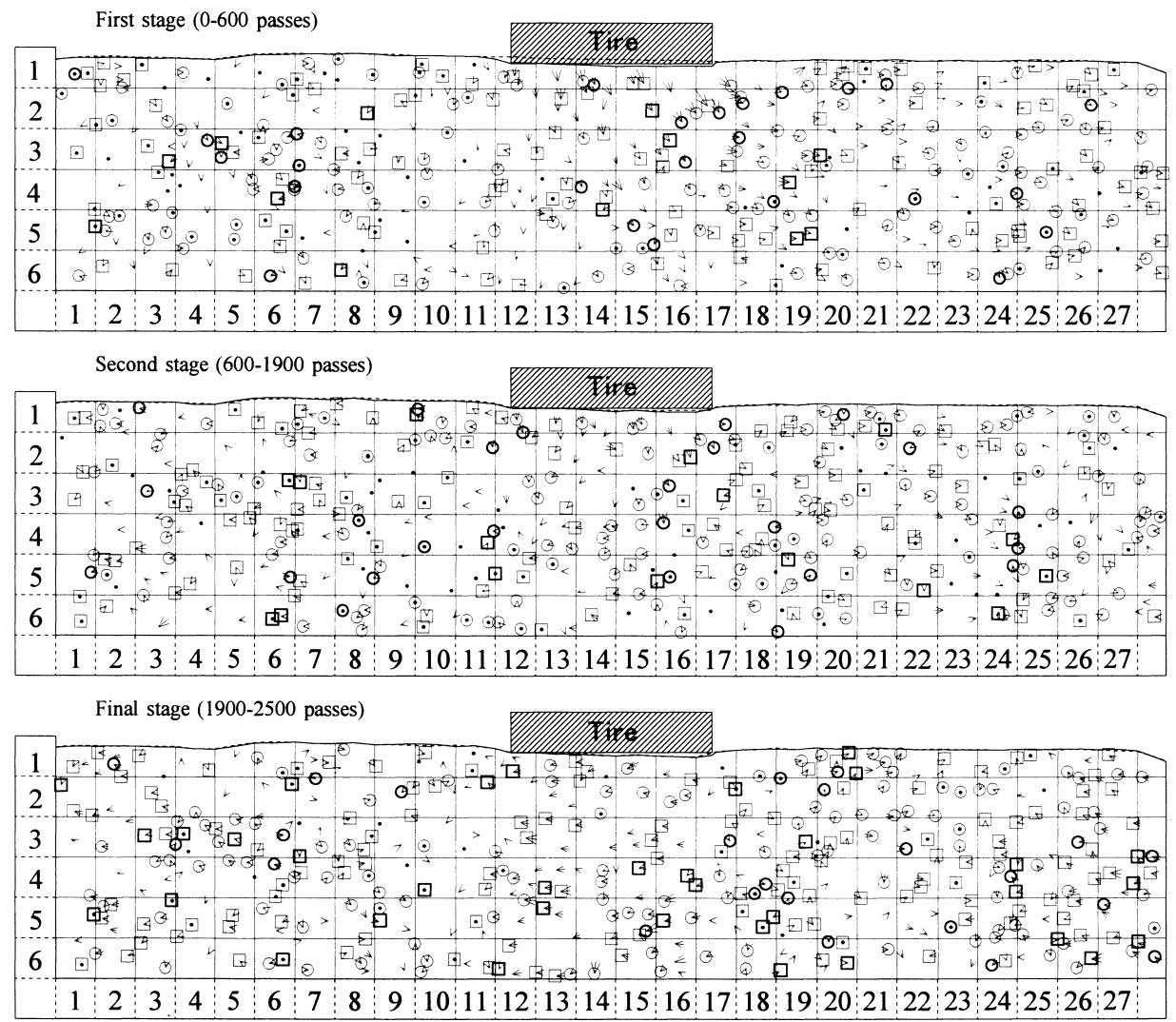

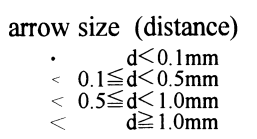

rotation angle $(\theta)$

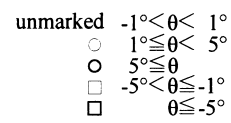

mesh scale

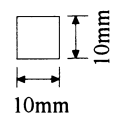

vector scale

$\underset{I}{\underline{E}}$

Fig. 8 Movement of Aggregates (reciprocating motion, vertical direction)

いている。よって，中期での骨材の動きは，往復走行では全体 的に側方への流動が主であり，一方向走行では荷重載荷部の上 層部で圧密，下層部㧍よび荷重側方部で側方への流動が主であ る。

\section{（3）後期の動き}

往復走行での荷重載荷部の骨材では, 鉛直下方向に動く骨材 はほとんど見られず，側方への動きであることから流動を主と した動きであると考えられる。これに対し，一方向走行の荷重 載荷部の骨材も側方へと動く骨材が多く見られるが，底面から $20 \mathrm{~mm}$ 上部程度では鉛直下方向への動きを伴っている骨材が見 られ，中期の動きとは逆になっている。このことから，荷重載 荷部の圧密は往復走行の場合は深さ方向全体で同時に進行する が，一方向走行の場合は上部から下部へと徐々に進行する傾向 があると考えられる。よって，一方向走行の荷重載荷部上部扮 よび荷重側方部では流動，下部では圧密を主とした動きである と考えられる。また，3.2.2.の体積変化からの変形特性の推定 において, 一方向走行の後期に荷重載荷部の圧密による体積の 減少割合が増加しているのは, アスファルト混合物の下部まで 圧密が進行したことにより, 底面部付近のアスファルト混合物 の側方への流動が減少したためであると考えられる。

ここで，WT試験時における荷重直角方向の骨材の動きから 走行方法別にアスファルト混合物内部の変形特性の検討を行 う。

まず，往復走行の場合は，走行荷重が写真撮影面の方向に移 動するとアスファルト混合物の内部は写真撮影面の方向へと押
し出される動きが生じる。逆に, 走行荷重が写真撮影面から遠 ざかる方向に移動すると, アスファルト混合物の内部も写真撮 影面から遠ざかる方向へと引き戻される動きが生じる。このた め, 走行荷重が通過する度にアスファルト混合物の内部は走行 荷重の移動方向に合わせて動くことによりニーディングが生 じ, 荷重載荷部のアスファルト混合物は初期に締め固められ, 圧密が終了すると考えられる。また, 走行荷重が往復すること により, アスファルト混合物の内部は走行荷重の移動方向に合 わせて動くが荷重載荷部付近での動きが主であり, 走行荷重に よる横断方向への荷重の伝達する幅が狭いと考えられる。

しかし, 一方向走行の場合には走行荷重は写真撮影面の方向 のみの移動であるため, アスファルト混合物の内部の動きは写 真撮影面の方向への動きに限定される。このため, 一方向走行 では荷重走行によるニーディングが生じ難いと考えられる。 よって, 一方向走行では荷重載荷部での圧密が生じ難く, 往復 走行と比較して圧密が終了するまでに時間を要すると考えられ る。また, 走行荷重による横断方向への荷重の伝達する幅が広 く, 荷重直下抢よび荷重側方部分のアスファルト混合物が幅広 く側方へと押し出されるため, 走行荷重のタイヤ両端から 50 $\mathrm{mm}$ 程度離れた表面付近で隆起する方向へと動く骨材が見られ ると考えられる。ここで, 既往の研究結果 ${ }^{\text {() }}$ により, 一方向走 行下では, 荷重載荷部の最大変形は走行開始点より走行長の約 5/6の地点で生じることが明らかにされている。このことから， 本実験では供試体型枠により供試体前面（写真撮影面）が拘束 されていることから, 最大変形が生じる箇所は写真撮影面から 

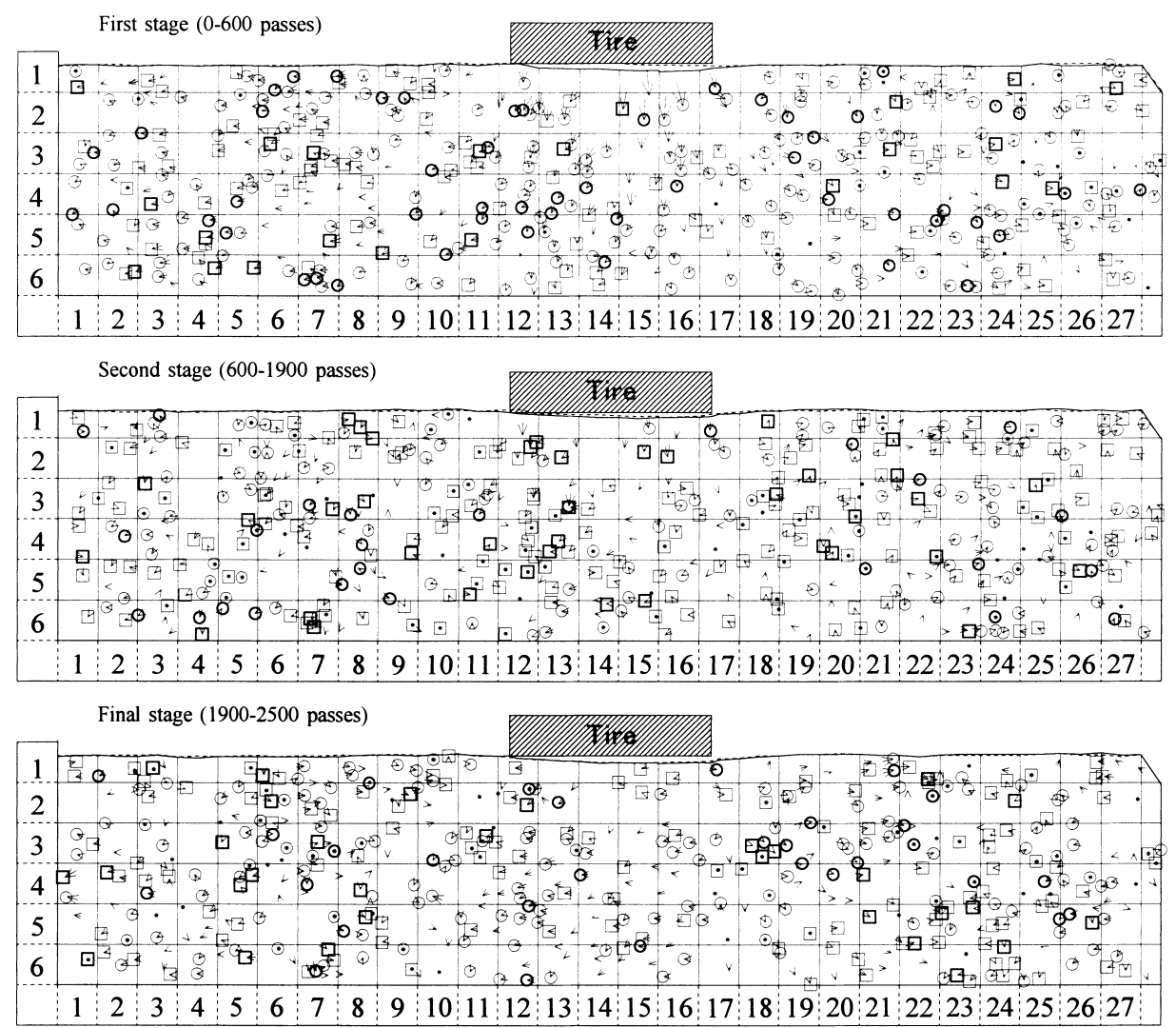

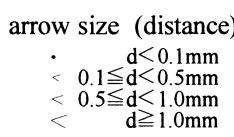

rotation angle $(\theta)$ unmarked $-1^{\circ}<\theta<1^{\circ}$ $1^{\circ} \leqq \theta<5$

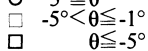

mesh scale

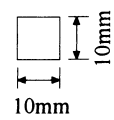

vector scale

政

Fig. 9 Movement of Aggregates (one-way motion, vertical direction)

40～50 mm 程度後方となり，実際の動きは解析結果より若干大 きくなると考えられる。

\subsection{3. 荷重側面方向の骨材の動きおよび回転}

Fig. 10 に往復走行，Fig. 11 に一方向走行時の荷重側面方向 の解析結果を示す。また，WT試験機の機構により供試体左側 の $40 \mathrm{~mm}$ （1４列）には荷重が載荷しないため，荷重走行距 離は両走行方法ともに $240 \mathrm{~mm} （ 5$ 列〜供試体右端）である。 また，文献6)によると，走行荷重による表面の低下量は走行幅 に打いて一定とはならず，往復走行では走行幅の中央，一方向 走行では走行開始点より走行長の約 5/6 $(200 \mathrm{~mm})$ の地点とな ることが報告されている。よって，本実験結果において表面の 沈下量が最大となる場所は，往復走行ではFig. 10の 15～17列 となり，一方向走行では未載荷部分の $40 \mathrm{~mm}$ を考慮して，Fig. 11の23〜25列となる。

\section{(1) 初期の動き}

往復走行では 1 9列程度までの骨材に左側へと流動が生じ ており，一方向走行では未載荷部分の骨材に大きな動きは見ら れない。よって, 本研究では供試体左端から $100 \mathrm{~mm} （ 1 \sim 10$ 列）までの骨材の動きには走行荷重の未載荷部分の影響が含ま れている可能性が考えられることから以降の中期，後期を含め 考察の対象外とする。

往復走行では，全体的に鉛直下方向へと骨材は動いており圧 密が生じている。一方向走行でも鉛直下方向へと動く骨材が多 く見られるが，右側（19列～右側端部）では走行方向へ流動 が生じている。このことから，走行荷重直下での骨材の動きは
往復走行では鉛直下方向への圧密が主であり，一方向走行では 鉛直下方向への圧密拉よび走行方向への流動が同時に生じてお り, 内部の動きは走行方法により異なっている。また, 鉛直下 方向への動きは往復走行の方が大きい。しかし，WT試験後の 表面の変形量は往復走行より一方向走行の方が大きかったこと から矛盾が生じる。このことについては3.3.5.で検討する。

また，往復走行の方が大きな回転を伴う骨材が多く見られる。 (2) 中期の動き

往復走行での骨材は側方へと動いている。これは, 初期に鉛 直下方向への骨材の動きにより圧密が終了したためであると考 えられる。一方向走行での骨材はわずかであるが，上層部では 鉛直下方向，下層部では側方へと動いている。

また，初期と同様に往復走行の方が大きな回転を伴う骨材が 多く見られる。

(3) 後期の動き

往復走行での骨材は移動がほとんど生じていないが，大きな 回転を示す骨材が多く見られる。このことから，往復走行での 圧密および流動は中期までにほぼ終了していると考えられる。 一方向走行での骨材はわずかであるが一様に側方へ動いてい る。そして, 走行開始点より中央付近 $(5 \sim 15$ 列 $)$ では左側へ と動く骨材が多く, 中心部より右側（16～供試体端部）では右 側へ動く骨材が多く見られ，大きな回転を伴う骨材が増加して いる。これは, 初中期の走行荷重の影響により, 圧密が終了し 側方への流動へと変化したためであると考えられる。また，走 行開始点から中央部（1１5列）までの骨材の動きは, 走行荷 

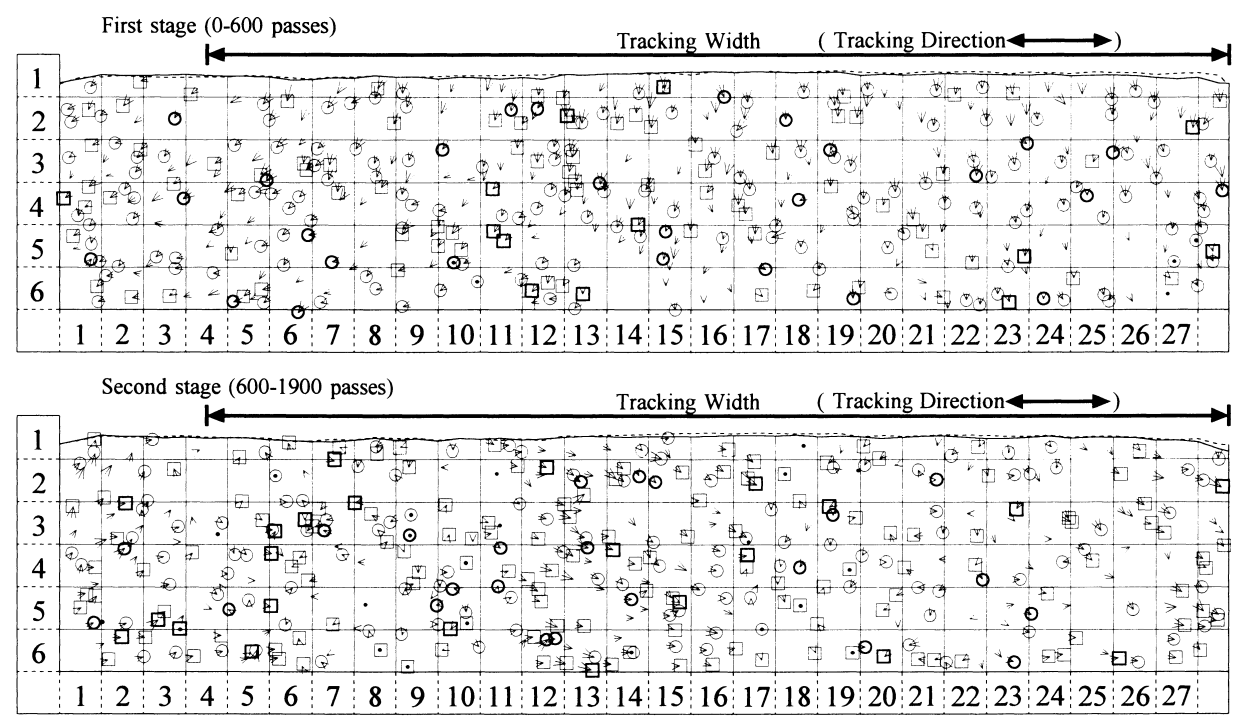

Final stage (1900-2500 passes)

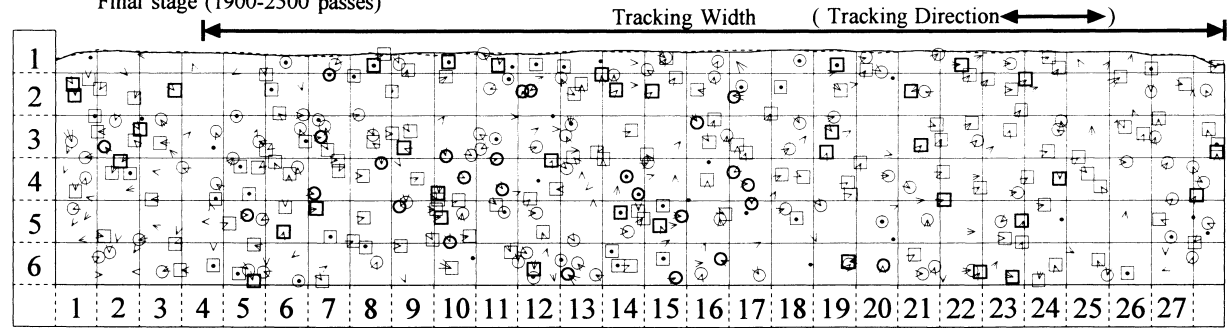

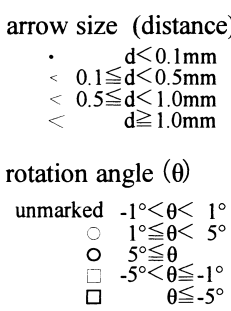

mesh scale

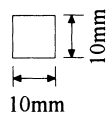

vector scale

$$
\underset{1 \mathrm{~mm}}{\searrow}
$$

Fig. 10 Movement of Aggregates (reciprocating motion, wheel direction)

重の影響を受けていない未載荷部分（1４列）への流動であ ると考えられる。よって, 実際の車両走行時と同様の動きを示 すのは供試体の中央から右側（15列～供試体端部）であると仮 定すると，一方向走行での骨材は走行方向へとわずかに動いて いると考えられる。

以上より，荷重直角方向と同様に，走行方向が異なると内部 の骨材の動きに違いが現れている。往復走行では走行荷重が前 後に動くことから鉛直下方向への圧密変形が卓越して生じ，一 方向走行では走行荷重が一方向のみに動くことから圧密拉よび 走行方向への流動が同時に生じている。

\section{3. 4. 解析方向の違いによるアスファルト混合物の変形特 性に対する検討}

3.3.2.および3.3.3.において, WT試験時の荷重直角方向お よび荷重側面方向の骨材の動きについて解析を行ったが，解析 の方向により表面の変形量および内部の骨材の移動量が異なる 結果となった。以下に，その問題点と原因について明らかに し，本解析結果の妥当性の検討を行う。

（1）WT試験から得られた表面の変形量が荷重直角方向と荷重 側面方向で異なる。

WT試験（2500 pass）後の表面の変形量は, 荷重直角方向で は往復走行が $0.90 \mathrm{~mm}$ ，一方向走行では $1.85 \mathrm{~mm}$ であるのに対 し, 荷重側面方向では往復走行, 一方向走行ともに $0.90 \mathrm{~mm}$ あった。

まず，Figs. 8，9に示した荷重直角方向の解析結果より，荷 重載荷部表面の変形を見ると夕イヤ幅で一様とはなっていない
ことがわかる。これは，走行輪による荷重の分布がタイヤ幅で 等分布とはならず，タイヤ中央部で最大值を示す放物線状の分 布荷重となり, タイヤ両脇付近ではやや小さな分布荷重となっ ているためであると考えられる。

ここで，本研究でのWT試験時の表面の変形量は撮影された 写真により解析を行っている。よって, 荷重直角方向では走行 荷重の走行位置が供試体の中央であるため夕イヤ中央部での表 面の変形量となり, 荷重側面方向では走行荷重の走行位置が供 試体の端部であるため夕イヤ端部での表面の変形量となる。こ の影響は, 往復走行よりも一方向走行で顕著に現れており, 解 析の結果, 荷重直角方向の一方向走行時に扔ける夕イヤ中央部 とタイヤ両脇の表面の変形量の差は $1.0 \mathrm{~mm}$ 程度であった。

よって, 表面の変形量の違いは, WT試験時に走行部分のア スファルト混合物が走行輪から受ける分布荷重がわずかに異な るためであると考えられる。

（2）荷重載荷部の骨材の動きは, 荷重直角方向では一方向走行 の方が大きいのに対し, 荷重側面方向では往復走行の方が大き い。

WT試験時のアスファルト混合物は, 写真撮影面でガラス板 により拘束されている。これにより，荷重直角方向では走行方 向, 荷重側面方向では横断方向への変形が抑制されることから 両者の骨材の動きに違いが現れていると考えられる。

Fig. 8 に示した往復走行の荷重直角方向の解析結果では, 走 行荷重の境界部（12，17列）の内，17列の骨材に鉛直下方向 および側方への動きが生じている。これに対して, Fig. 10 に 

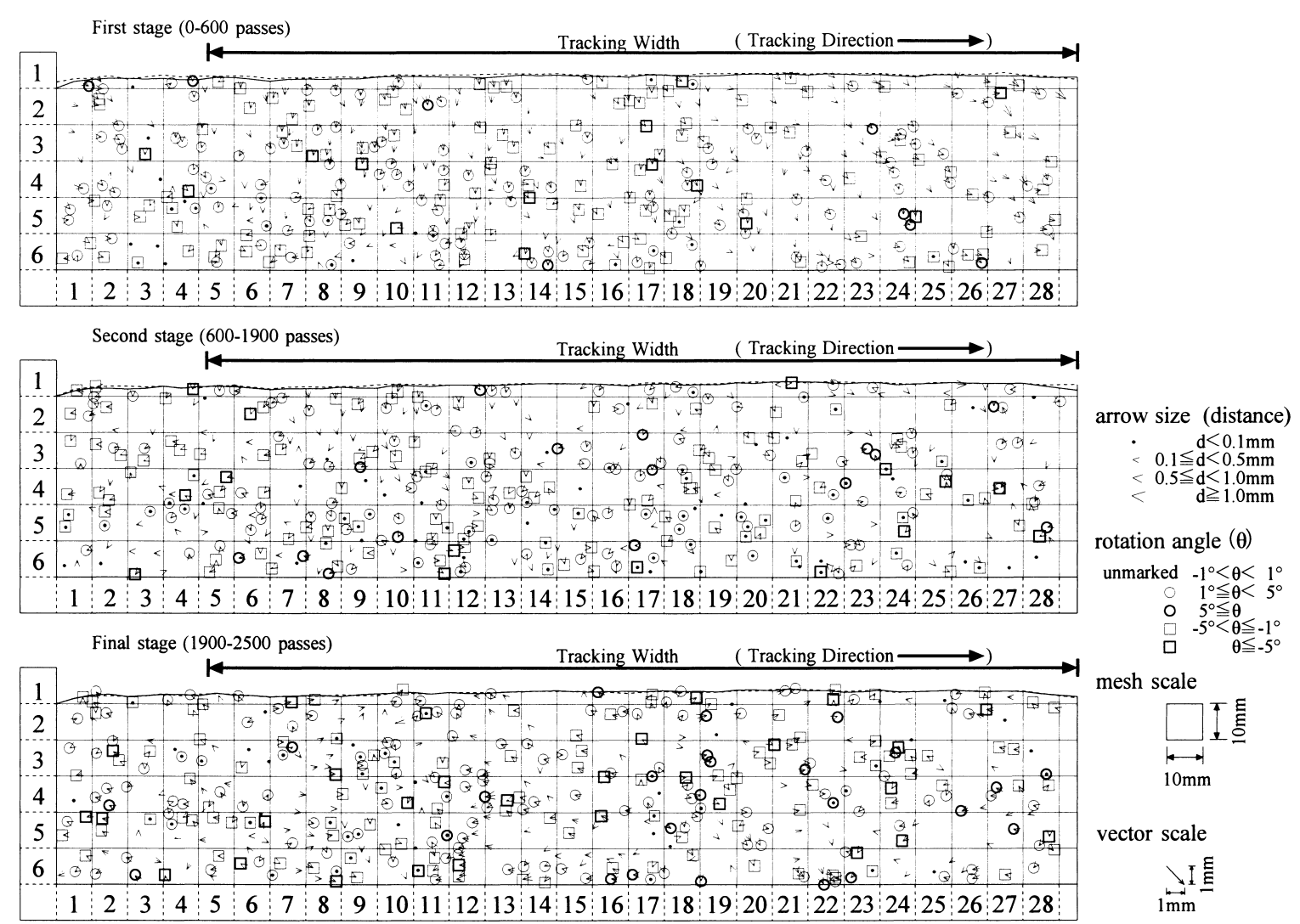

rotation angle $(\theta)$ unmarked $-1^{\circ}<\theta<1^{\circ}$ $\begin{aligned} \circ & 1^{\circ} \leqq \theta<5^{\circ} \\ \circ & 5^{\circ} \leqq \theta \\ -5^{\circ} & <\theta \leqq-1^{\circ}\end{aligned}$ $\square-5^{\circ}<\theta \leqq-1^{\circ}$ mesh scale

$$
\begin{aligned}
& \downarrow_{\longmapsto} \underbrace{\mathbb{E}} \\
& 10 \mathrm{~mm}
\end{aligned}
$$

vector scale

$$
\underset{1}{1}
$$

Fig. 11 Movement of Aggregates (one-way motion, wheel direction)

示した往復走行の荷重側面方向の解析結果では, 側方への骨材 の動きは写真撮影面の供試体型枠により抑制される。この影響 により，側方への骨材の動きが鉛直下方向へと変換され，荷重 側面方向の解析結果では, 全体的に鉛直下方向への骨材の動き が大きくなっていると考えられる。

Fig. 9に示した一方向走行の荷重直角方向の解析結果から, 荷重載荷部では鉛直下方向への動きが大きく, 荷重側方部分で は側方への骨材の動きが生じている。しかし, 走行荷重の境界 部 (12，17列の中央部分）の骨材の動きは中央部 (14, 15列) と比較すると小さい。また, 側方への骨材の動きは上層部で生 じているが，中下層部では生じていない。これに対して，Fig. 11 に示した一方向走行の荷重側面方向での解析結果では, 側 方への骨材の動きは写真撮影面の供試体型枠により抑制され る。この影響により, 上層部で生じている側方への骨材の動き が鉛直下方向へと変換され, 荷重側面方向の解析結果では, 上 層部での鉛直下方向への骨材の動きが大きくなっていると考え られる。

以上より, 骨材は写真撮影面の供試体型枠により写真撮影面 を直角に貫く方向への動きが抑制されるため, 鉛直下方向への 動きが大きく現れていると考えられる。しかし，写真撮影面の 供試体型枠による拘束は骨材の動きの大小, 特に鉛直下方向へ の骨材の動きに影響を与えているが, 写真撮影面のアスファル 卜混合物全体の変形特性または傾向が大きく変化するほどでは なく, 本解析結果は妥当であると考えられる。

\subsection{5. 走行荷重によるアスファルト混合物に作用するカ}

Fig. 12 に本解析結果から考えられる走行荷重によるアス ファルト混合物に作用する力の分布を示す。

荷重側面方向から見た場合, 走行荷重が右側へ移動すると走 行による力 $($ Fig. 12 中(a) ) は, 走行方向の斜め鉛直下方向へ 伝わる。また, 走行荷重の回転による力 (Fig. 12中(b)）は, タイヤ接地部では走行荷重の移動により前方の表面へと伝わる とともに, タイヤとアスファルト混合物表面の摩擦により後方 の表面へと伝わる。しかし, タイヤ接地部の前方の表面の動き は, 直後に走行荷重が通過するため変形に大きな影響を与えな いと考えられる。また, 左側への走行時には, これと逆の力が 作用する。

荷重載荷部では走行による力 $($ Fig. 12 中 (c) ) が走行方向の 底面へと伝わる。そして, 荷重直角方向から見た場合, 回転に よる力 $($ Fig. 12 中 $(\mathrm{d}))$ は走行方向の表面へと伝わる。また, 後方にも同様に表面へ力が伝わっていると考えられる。ただ し, 走行方向への力ょりは小さい（図が煩雑になるため後方へ の力は描いていない)。

このような力の伝達により, 往復走行時の往路では走行荷重 前方へ圧密が大きく作用し, 走行荷重の後方へは流動により表 面付近が若干緩む作用が生じる。そして, 復路ではこの緩みが 走行荷重により, 締め固められるためニーディングが生じてい ると考えられる。また, 走行荷重の側方では, 走行方向の前方 の表面へと押し出された部分が復路では後方へと引き戻される 


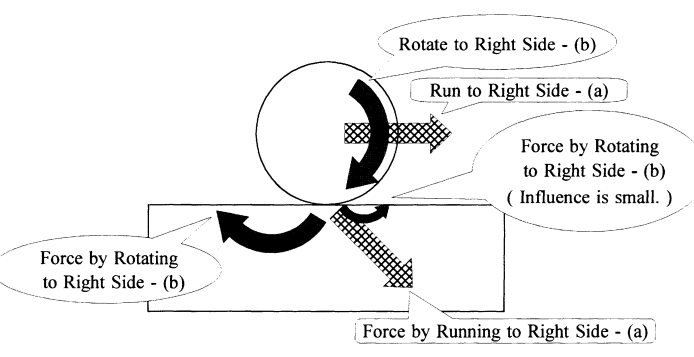

Side View (Case of Running to Right Side)

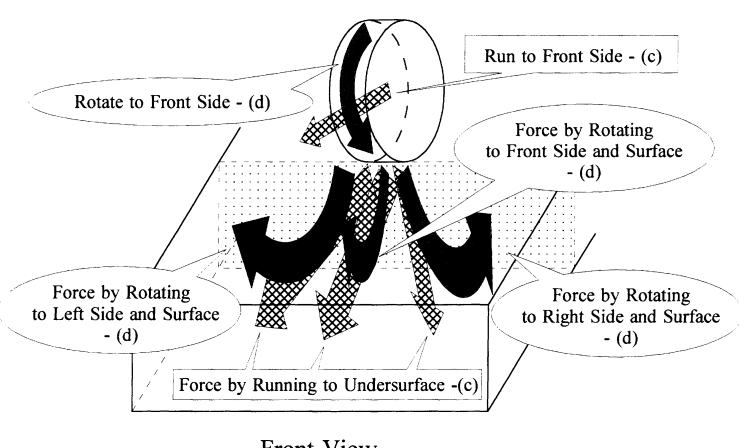

Front View

Meaning of Arrow ( to Wheel Load )

Meaning of Arrow ( in Asphalt Mixture )
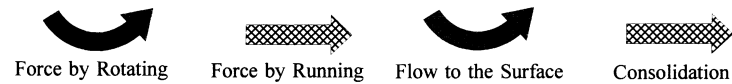

Consolidation to the Undersurface

The size of the arrow varies depending on the weight or type of the load and kind of asphalt mixture.

Therefore, the size and the direction of the arrow show the trends.

Fig. 12 Distribution of Force in Asphalt Mixture

ことになる。このため, 荷重直角方向からの解析結果のように 往復走行では, 荷重載荷部の骨材の動きが大きく, 側方の骨材 の動く幅が狭いため荷重側方表面の隆起が小さいと考えられ る。

また，一方向走行では往路のみの力の伝達であることから， 走行荷重の側方や後方への緩みが引き戻されないため, 荷重載 荷部や側方への骨材の動きが大きくなる。よって，走行荷重の 側方に生じる隆起は往復走行より一方向走行の方が大きく, 走 行荷重の両端より離れた箇所に発生すると考えられる。

\section{3. 6. 一方向走行によるWT試験の有効性に対する検討}

本項では，WT試験時の走行方法やアスファルト混合物の種 類や配合の違いにより，表面の変形量および隆起の発生箇所が 異なることと, 表面の隆起の発生箇所や高さが実道でのわだち 掘れの計測結果に与える影響を述べた後, 一方向走行による WT試験を取り入れる有効性に対する検討を行う。

（1）WT試験の結果から，アスファルト混合物に生じる表面の 変形量は往復走行より一方向走行の方が大きく，表面の隆起の 発生箇所は往復走行より一方向走行の方が載荷部から遠地点に 発生する ${ }^{6}$ 。

（2）一方向走行による車両走行では，同種類のアスファルト混 合物の場合，アスファルト量が多い方が表面の隆起は載荷部か ら遠地点に発生し6), 同配合のアスファルト混合物の場合, ア
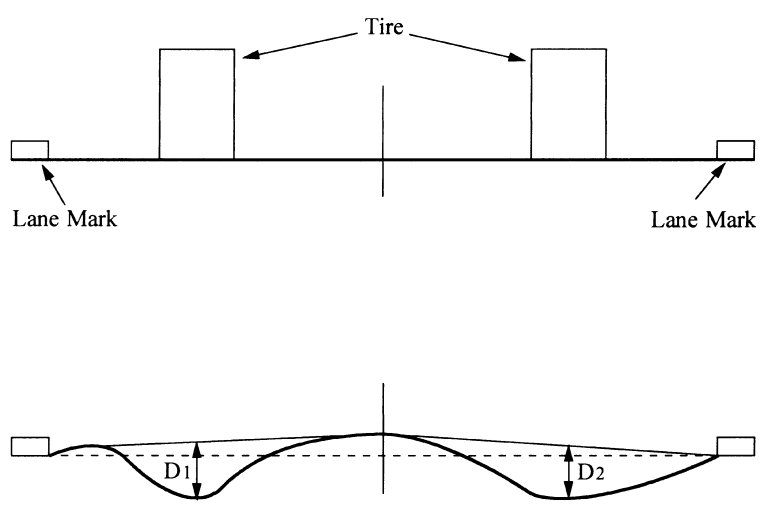

Upheaval of the Center Lane was Higher than Upheaval of both Sides

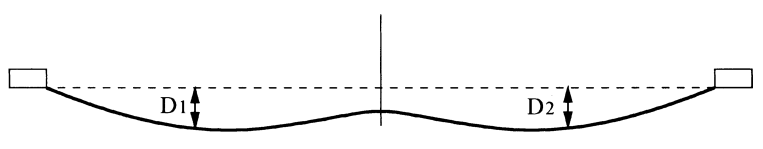

Upheaval of the Center Lane was Lower than Upheaval of both Sides

Average Method (Wire Method)

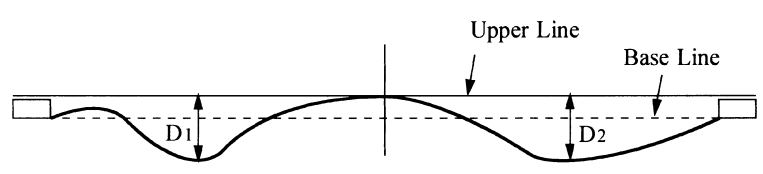

Upheaval of the Center Lane was Higher than Base Line

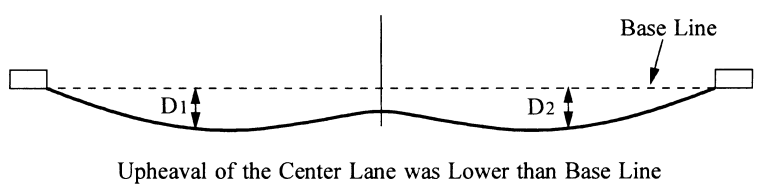

Peak Method

Fig. 13 Method of Rut Depth Determination

スファルトバインダーの粘度が高いと表面の隆起が生じない, または車両走行部から遠地点に発生する ${ }^{10)}$ 。

（3）実道におけるわだち掘れの計測は一般的に平均法（ワイ ヤー法）とピーク法が使用されている (Fig. 13参照 $)^{11)}$ 。ここ で, 両計測方法ともに表面の隆起が基準線または施工直後の路 面よりも高い場合 (両計測方法ともに Fig. 13中の上段の図) には, 計測されるわだち掘れ量が表面の隆起の発生箇所や高さ に影響を受けるため, WT試験により計測されるわだち掘れ量 とは異なる部分を計測していることとなる。

このように, WT試験時の走行方法や実道でのわだち掘れの 計測方法, 計測部分の違いが, WT試験から得られるわだち掘 れ量の予測と実道でのわだち掘れ量の検討を困難にしている一 因となっていると考えられる。

以上のように, 車両走行部の側方に生じる表面の隆起はわだ ち掘れに関して重要な問題であり, 室内で行われるWT試験に おいてもわだち掘れ量とともに荷重側方部の隆起を含めた検討 が必要であると考えられる。よって, 本研究で行った往復走行 

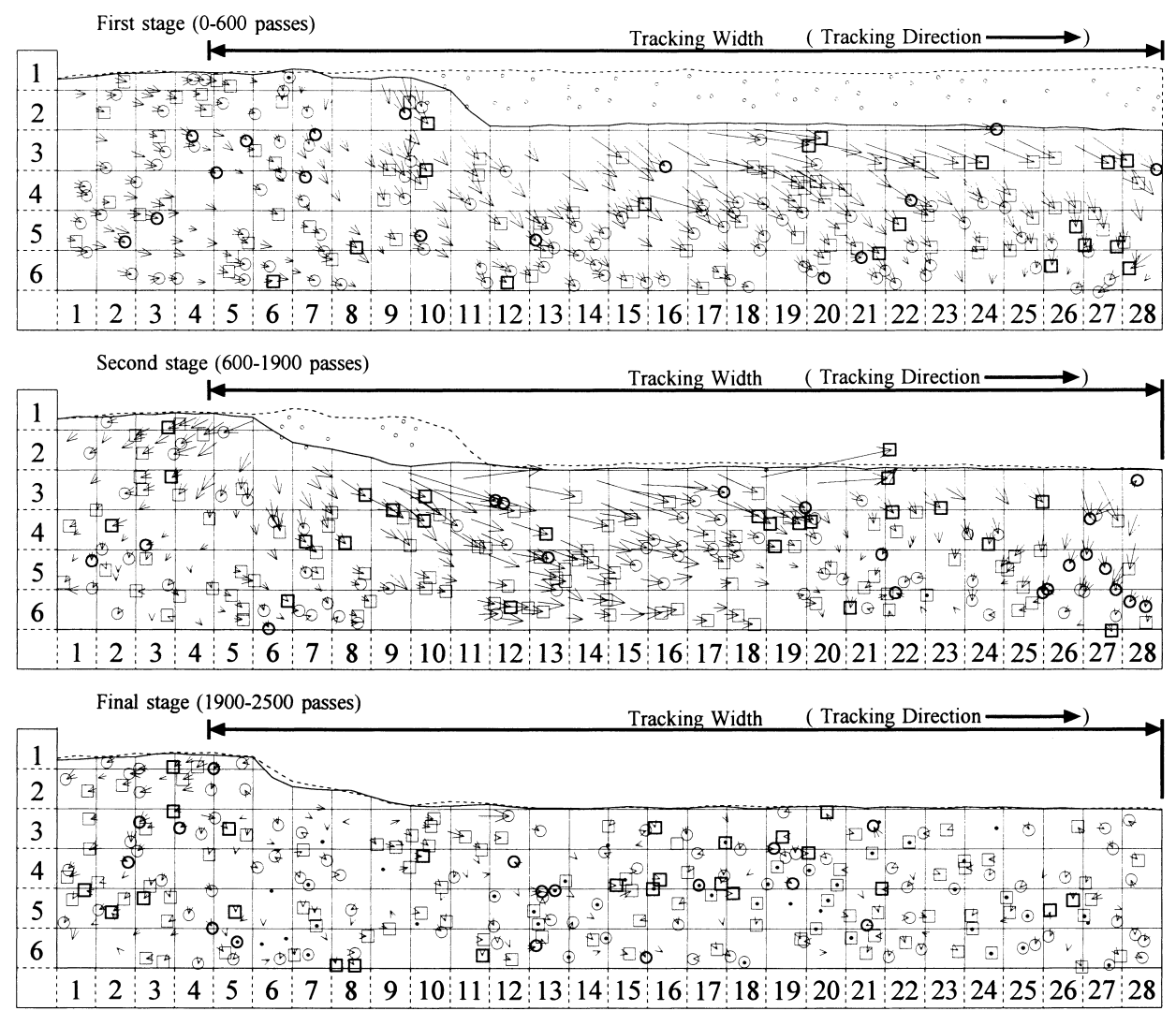
arrow size (distance)
lost by wear
$\mathrm{d}<0.1 \mathrm{~mm}$
$0.1 \leqq \mathrm{~d}<0.5 \mathrm{~mm}$
$\mathrm{d} \geqq 1.0 \mathrm{~mm}$

rotation angle $(\theta)$ unmarked $-1^{\circ}<\theta<1^{\circ}$ ○ $1^{\circ} \leqq \theta<5^{\circ}$ ․ $-5^{\circ}<\theta \leqq-1^{\circ}$

mesh scale

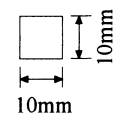

vector scale

I

Fig. 14 Movement of Aggregates (one-way motion with braking, wheel direction)

と一方向走行では WT試験時の表面の変形量，体積変化，内部 の骨材の動き，および表面の隆起が生じる箇所が異なっていた ことから，一方向走行によるWT試験はわだち掘れ現象の検討 に有効であると考えられる。

\subsection{7. ブレーキ走行時の骨材の動きおよび回転}

Fig. 14 にブレーキ走行時の荷重側面方向の解析結果を示す。 ブレーキ走行での荷重走行距離は荷重側面方向と同様に 240 $\mathrm{mm}$ である。また，ブレーキ走行開始地点から $10 \mathrm{~mm}$ 程度は完 全にブレーキがかかるまでの余裕がある。よって，Fig. 14 に おいて5列目では夕イヤに若干の回転が生じ，6列目より右側 で完全にタイヤがロックされた状態での走行となる。

\section{（1）初期の動き}

ブレーキ走行時の骨材は，往復走行および一方向走行と比較 して非常に動きが大きく，一様に鉛直下方向および走行方向へ と動いている。また，上層部から下層へと順に動きが小さく なっている。しかし，大きな回転を伴っている骨材は少ない。 初期での骨材の動きは圧密招よび流動によると考えられるが, タイヤを回転させて走行した場合とは異なり，圧密は荷重の影 響により生じ，側方への動きはタイヤの摩擦により生じている と考えられる。

また，表面が約 $13 \mathrm{~mm}$ 程度摩耗により削り取られているが, ブレーキ開始地点（6列目）からではなく，10列目から削られ ている。これは，表面付近は右側から削られていったため，初 期ではブレーキ開始地点にまで達しなかったためである。ま た，供試体右端部（24列付近〜右側端部）では，動きが小さ
い骨材や左側へと動く骨材が見られるが，これは供試体型枠の 影響である。

（2）中期の動き

初期と同様に鉛直下方向扮よび走行方向へと動く骨材が多 い。しかし，鉛直下方向への動きは小さくなり，走行方向への 動きが大きくなっている。よって, 荷重による圧密は終了に近 づき，夕イヤの摩擦により引きずられる影響が大きく現れてい ると考えられる。

そして，摩耗による表面の削れはブレーキ開始地点にまで及 んでいる。また，供試体右端部で動きが小さい骨材の幅が広 がっているが，これは供試体右側が初期において締め固めら

れ，供試体内部が密になったためであると考えられる。

（3）後期の動き

表面の変形はほとんど生じていないことから，夕イヤの摩擦 による摩耗は生じていないと考えられる。また，内部の骨材の 移動もほとんど生じていない。しかし，大きな回転が生じる骨 材が増加している。これは, 初中期の走行により供試体内部が 安定的な状態となった, 夕イヤの摩擦の影響が内部や底面付近 にまで及ぶようになった, あるいは夕イヤの摩擦により締め固 められた部分が走行開始地点にまで及び走行方向への動きが抑 制されているためと考えられる。

\section{4. 結 言}

本研究から明らかになった往復走行と一方向走行よるWT試 験から得られたアスファルト混合物の変形特性の違いを以下に 
まとめる。

(1) 走行方法が異なると表面の変形量に違いが生じる。これは, 初期の圧密変形量に関係しており，DSには変化が生じない。

（2）走行方法が異なると荷重載荷部および側方の骨材の動きに 大きな違いが生じる。これは, 走行方法によりアスファルト混 合物内部に作用する力が違うことが影響を及ぼしている。

（3）走行方向が異なると走行荷重の側方の表面に生じる隆起の 発生箇所が異なる。

よって, わだち掘れのみではなく側方の隆起も含めたアス ファルト混合物の変形性状を踏まえた検討を行うためには, WT 試験は従来の往復走行とともに，実際のアスファルト舗装 に损ける載荷条件と同様の一方向走行で行うことも有効である と考えられる。

ブレーキ走行では, タイヤを回転させて行ったWT試験より も大きな変形が生じ，骨材の動きは鉛直下方向よりも走行方向 の方が大きい。これは，夕イヤの摩擦によりアスファルト混合 物の内部が走行方向へ引きずられるためである。よって，実際 のアスファルト舗装に扔いて，車両のブレーキ操作が頻繁に必 要となる場所では流動によるわだち掘れおよび摩耗によるわだ ち掘れが生じると考えられる。

\section{References}

1) Omoto, S., Hosou, 38, (10), 3 (2003).

2) Japan Road Association, "Manual for Test Method of Pavement (Separate Volume)," Maruzen Co., Ltd., Tokyo (2000), p. 116-138.

日本道路協会, “舗装試験法便覧別冊（暫定試験法）, 丸善, 東京 (2000), p. 116-138.

3) Ray Brown, E., Kandhal, S., Zhang, J., NCAT Report No. 0105, 1 (2001).

4) Kandhal, S., Cooley Jr., L. A., NCAT Report No. 2002-08, 1 (2002).

5) Cooley Jr., L. A., Kandhal, S., Buchanan, M. S., Transportation Research, E-C016, 1 (2000).

6) Sano, M., Journal of JSCE, 426, 233 (1991)

7) Hand, A. J., Epps, J. A., Sebaaly, P. E., Offered for Presentation and Publication at the International Conference on Accelerated Pavement Testing, 17-20, 1 (1999).

8) Ricardo, A. R., Madanat, S., Journal of Transportation Engineering, 379, (2001).

9) Kondo, T., Moriyoshi, A., Yoshida, T., Takahashi, S., J. Jpn. Petrol. Inst., 46, (3), 172 (2003).

10) Thomas, D., White, J. E., Haddock, A. J. T., Hand, H. F., NCAT Report No. 486, (2002).

11) Inagaki, T., Hosou, 32, (1), 21 (1997).

要旨

載荷条件の異なるホイールトラッキング試験におけるアスファルト混合物の変形特性

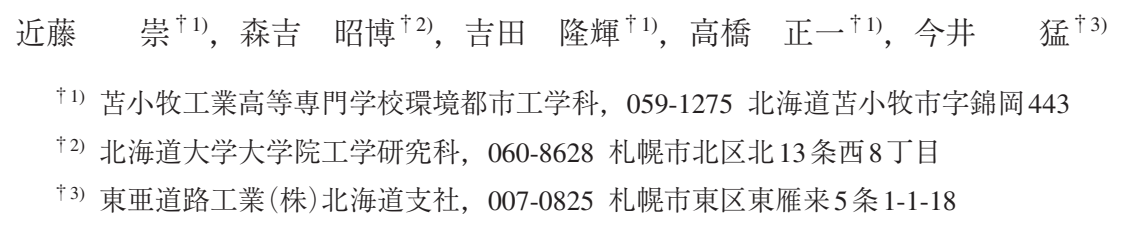

室外で作製した細粒度ギャップアスファルト混合物（13F） に関して，往復走行，一方向走行㧍よびブレーキ走行が可能な ホイールトラッキング（WT）試験機を用いて，ホイールト ラッキング試験中における内部の骨材の動きの違いを明らかに した。

解析結果より，ホイールトラッキング試験による走行荷重直 下のわだち掘れは往復走行より一方向走行の方が大きくなり， 側方部の隆起は往復走行では荷重端部の右側で生じ，一方向走 行では荷重端部から $50 \mathrm{~mm}$ 程度離れた箇所に生じた。また, 荷重直角方向の骨材の動きより，往復走行では圧密によるわだ ち掘れが主であり，一方向走行では流動によるわだち掘れが主
であることが明らかとなった。この結果から, WT試験は往復 走行とともに, 実際のアスファルト舗装と同様の走行方法であ る一方向走行も行うことが，横断方向への変形も含めたわだち 掘れ現象の解明につながると考えられる。

ブレーキ走行を行った結果より，タイヤの摩擦による骨材の 動きは鉛直下方向よりも走行方向の方が大きい。これは，夕イ ヤの摩擦によりアスファルト混合物の内部が走行方向へ引きず られるためである。よって, 車両のブレーキ操作が頻繁に必要 となる場所では, 流動によるわだち掘れおよび摩耗によるわだ ち掘れが生じると考えられる。 